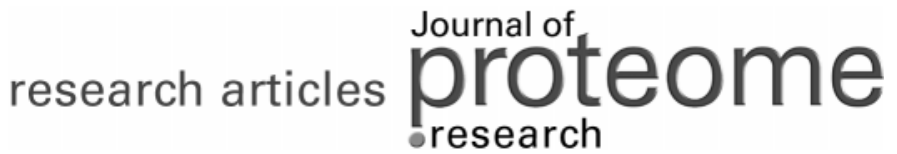

\section{Altered Proteome in Burkholderia pseudomallei rpoE Operon Knockout Mutant: Insights into Mechanisms of rpoE Operon in Stress Tolerance, Survival, and Virulence}

\author{
Visith Thongboonkerd, ${ }^{,+\dagger}$ Muthita Vanaporn, ${ }^{\ddagger}$ Napat Songtawee, ${ }^{\dagger}$ Rattiyaporn Kanlaya, ${ }^{\dagger, \ddagger}$ \\ Supachok Sinchaikul, ${ }^{\S}$ Shui-Tein Chen, ${ }^{\S, \|}$ Anna Easton, ${ }^{\perp}$ Karen Chu, ${ }^{\perp}$ Gregory J. Bancroft, ${ }^{\perp}$ and \\ Sunee Korbsrisate ${ }^{\ddagger}$ \\ Medical Molecular Biology Unit, Office for Research and Development, Faculty of Medicine Siriraj Hospital, \\ Mahidol University, Bangkok, Thailand, Department of Immunology, Faculty of Medicine Siriraj Hospital, \\ Mahidol University, Bangkok, Thailand, Institute of Biological Chemistry and Genomic Research Center, \\ Academia Sinica, Taipei, Taiwan, Institute of Biochemical Sciences, College of Life Science, National Taiwan \\ University, Taipei, Taiwan, and Department of Infectious and Tropical Diseases, London School of Hygiene \\ and Tropical Medicine, Keppel Street, London, United Kingdom
}

Received September 6, 2006

\begin{abstract}
We have previously shown that the alternative sigma factor $\sigma^{\mathrm{E}}$ (RpoE), encoded by $r p o E$, is involved in stress tolerance and survival of Burkholderia pseudomallei. However, its molecular and pathogenic mechanisms remain unclear. In the present study, we applied gel-based, differential proteomics to compare the cellular proteome of an $r p o E$ operon knockout mutant (RpoE Mut) to that of wild-type (K96243 WT) B. pseudomallei. Quantitative intensity analysis ( $n=5$ gels from 5 individual culture flasks in each group) revealed significantly differential expression of 52 proteins, which were subsequently identified by Q-TOF MS/MS. These included oxidative, osmotic, and other stress response proteins; chaperones; transcriptional/translational regulators; metabolic enzymes; proteins involved in cell wall synthesis, fatty synthesis, glycogen synthesis, and storage; exported proteins; secreted proteins; adhesion molecule; protease/peptidase; protease inhibitor; signaling proteins; and other miscellaneous proteins. The down-regulation of several stress response proteins, chaperones, transcriptional/ translational regulators, and proteins involved in cell wall synthesis in RpoE Mut provided some new insights into the mechanisms of the rpoE operon for the stress tolerance and survival of $B$. pseudomallei. In addition, the proteomic data and in vivo study indicated that the rpoE operon is also involved in the virulence of $B$. pseudomallei. Our findings underscore the usefulness of proteomics for unraveling pathogenic mechanisms of diseases at the molecular level.
\end{abstract}

Keywords: Proteome • Proteomics • Melioidosis • Burkholderia • RpoE • Stress tolerance • Survival • Virulence

\section{Introduction}

Burkholderia pseudomallei is a Gram-negative bacillus found in soil and water and is the causative agent of melioidosis, a disease of which clinical manifestations can be acute or chronic. Organ involvement in melioidosis ranges from local to systemic, and its severity varies from mild to fatal. Almost all organs, with the exception of hair and nails, can be affected

* To whom correspondence should be addressed. Visith Thongboonkerd MD, FRCPT, Medical Molecular Biology Unit, Office for Research and Development, 12th Floor Adulyadej Vikrom Building, 2 Prannok Road, Siriraj Hospital, Bangkoknoi, Bangkok 10700, Thailand. Phone/fax, +66-2-4184793; e-mail, thongboonkerd@dr.com or vthongbo@yahoo.com.

${ }^{\dagger}$ Office for Research and Development, Faculty of Medicine Siriraj Hospital, Mahidol University.

${ }^{\ddagger}$ Department of Immunology, Faculty of Medicine Siriraj Hospital, Mahidol University.

$\S$ Academia Sinica.

" National Taiwan University.

${ }^{\perp}$ London School of Hygiene and Tropical Medicine. by melioidosis. ${ }^{1}$ Mortality rates in patients with septic shock caused by melioidosis are approximately $80-95 \%$ despite adequate treatment. ${ }^{1}$ Previous studies on melioidosis have focused not only on the improvement of therapeutic outcome, but also on the understanding of the pathogenic mechanisms of this infectious disease. Moreover, B. pseudomallei has been considered as a potential bioterrorism weapon. ${ }^{2}$ Better understanding of the molecular basis and pathogenic mechanisms of this organism is, therefore, critically required for the discovery of new therapeutic targets and vaccine development for disease prevention.

As B. pseudomallei is a saprophyte found in soil and water, it is a difficult microorganism to kill, and it can survive in these environments for years. Additionally, this microorganism is resistant to several antibiotics, chemicals, organic compounds, and other stressful conditions. ${ }^{3}$ Moreover, it can survive within different eukaryotic cell types, including mammalian phagocytes. Thus, stress tolerance has been thought to be one of the 
important factors for the survival of $B$. pseudomallei both inside and outside of the human body. While much progress has been made regarding its virulence factors, that is, secretory proteins and cell-associated antigens, ${ }^{3}$ little is known about the stress tolerance of this bacterial pathogen.

In Escherichia coli, the alternative sigma factor $\sigma^{\mathrm{E}}$ (RpoE), encoded by rpoE, plays an important role in maintaining the integrity of the cell envelope (by controlling the transcription of several genes associated with cell envelope integrity) and is, thus, essential for viability of the bacterium. ${ }^{4}$ During stresses (heat stress, chemical exposure, etc.), RpoE is activated and transcribes genes in its regulon, including those encoding chaperones and proteases, which subsequently refold and degrade misfolded proteins, respectively. Recently, RpoE has been shown to play a critical role in survival, stress response, and virulence of several other bacteria, that is, Azotobacter vinelandii, ${ }^{5,6}$ Bacillus subtilis, ${ }^{7,8}$ Haemophilus influenzae, ${ }^{9}$ Mycobacterium tuberculosis, ${ }^{10}$ Pseudomonas aeruginosa, ${ }^{11,12}$ Pseudomonas fluorescens, ${ }^{13}$ Salmonella enterica, ${ }^{14}$ Streptomyces antibioticus, ${ }^{15}$ and Vibrio cholerae. ${ }^{16}$ More recently, we have demonstrated that the rpoE operon also plays a pivotal role in stress tolerance and biofilm formation in B. pseudomallei. ${ }^{17}$ These data underscore the significance of RpoE in various bacteria. However, the available information is limited and does not provide sufficient insights into the mechanisms of how the rpoE operon controls such functions in these bacteria.

In the present study, we explored further the mechanisms of the rpoE operon in controlling the stress tolerance and survival of B. pseudomallei. Fortunately, the complete genome sequence and annotation of B. pseudomallei (K96243 strain) have recently been made available. ${ }^{18} \mathrm{We}$, thus, performed a proteomic analysis of RpoE-associated proteins in B. pseudomallei. The cellular proteome of K96243 wild-type (K96243 WT) was compared with that of an rpoE operon knockout mutant (RpoE Mut) using a gel-based, differential proteomics strategy. The results showed that several components of stress response proteins were down-regulated in RpoE Mut. Additional findings were the down-regulation of two potential virulence factors. In vivo experiments using BALB/c mice showed that animals infected with RpoE Mut had a marked delay in time to death, indicating that the rpoE operon is also involved in the virulence of B. pseudomallei.

\section{Materials and Methods}

Bacterial Culture. B. pseudomallei K96243 WT (kindly provided by Prof. T. Dharakul) and rpoE operon mutant (RpoE Mut) ${ }^{17}$ were maintained in Luria-Bertani (LB) broth at $37^{\circ} \mathrm{C}$ until the stationary phase was reached. The RpoE Mut was constructed as described previously by Korbsrisate et al. ${ }^{17}$ Briefly, a 270-bp internal fragment of the putative rpoE coding sequence was PCR-amplified from B. pseudomallei K96243 genomic DNA using the primers ALG36 (5' CTC CAA ATA CCA CCG CAA GAT 3') and ALG37 (5' TAT CCC TTA GTT GGT CCG $3^{\prime}$ ), which correspond to B. pseudomallei rpoE nucleotides at the positions of 78-98 and 332-349, respectively. The 270-bp PCR product was cloned into the EcoRV restriction site of the pKNOCK-Cm vector ${ }^{19}$ to create pPK-1. This construct was introduced from E. coli $\mathrm{S} 17-1 \lambda$ pir $^{20}$ into B. pseudomallei K96243 by conjugation. An insertion mutant was selected on Pseudomonas agar supplemented with SR103 and $30 \mu \mathrm{g} / \mathrm{mL}$ chloramphenicol.

Southern Blot Analysis. Southern blot hybridization was done according to the method described by Southern. ${ }^{21}$ Briefly, chromosomes of both strains were digested with restriction enzymes, including XhoI and XhoI/EcoRV, and separated by agarose gel electrophoresis. DNAs in the gel were denatured and transferred onto a nylon membrane using a capillary blotting system. The blot was fixed by baking at $80^{\circ} \mathrm{C}$ for $2 \mathrm{~h}$, then hybridized with a 270-bp rpoE homologue DNA labeled probe. After eliminating the nonspecific binding of probe, the hybridized bands were detected by radiography.

Protein Extraction for Proteomic Analysis. At the stationary phase with a comparable bacterial count, bacteria were collected using $1000 \mathrm{~g}$ centrifugation for $5 \mathrm{~min}$ and washed three times with phosphate-buffered saline (PBS). Bacterial proteins were extracted using a buffer containing $7 \mathrm{M}$ urea, $2 \mathrm{M}$ thiourea, 4\% 3-[(3-cholamidopropyl)dimethylamino]-1-propanesulfonate (CHAPS), 2\% (v/v) ampholytes ( $\mathrm{pH} 3-10), 120$ $\mathrm{mM}$ dithiothreitol (DTT), and $40 \mathrm{mM}$ Tris-base and incubated at $4{ }^{\circ} \mathrm{C}$ for $30 \mathrm{~min}$. After centrifugation at $12000 \mathrm{~g}$ for $5 \mathrm{~min}$, the supernatant was saved and the protein concentration was measured by spectrophotometry using the Bio-Rad Protein Assay (Bio-Rad Laboratories, Hercules, CA) based on Bradford's method. Because urea, thiourea, CHAPS, and other compositions in the sample/lysis buffer can interfere with the protein estimation, we generated the standard curve using bovine serum albumin at concentrations of $0,2,5,7$, and $10 \mu \mathrm{g} / \mu \mathrm{L}$ in the same sample/lysis buffer to ensure that the standards and the samples had the same background that might occur due to chemical interference. Proteins extracted from each cultured flask were further resolved in individual 2-D gels; $n=5$ gels (from 5 cultured flasks) for each group; total $n=10$ gels.

Two-Dimensional Electrophoresis (2-DE) and Staining. Immobiline DryStrip (nonlinear pH 3-10, 7 cm long; Amersham Biosciences, Uppsala, Sweden) was rehydrated overnight with $200 \mu \mathrm{g}$ of total protein (equal loading for each sample) that was premixed with a rehydration buffer containing $7 \mathrm{M}$ urea, $2 \mathrm{M}$ thiourea, $2 \%$ CHAPS, $2 \%$ (v/v) ampholytes (pH 3-10), $120 \mathrm{mM}$ DTT, $40 \mathrm{mM}$ Tris-base, and bromophenol blue (to make the final volume of $150 \mu \mathrm{L}$ per strip). The first dimensional separation (IEF) was performed in an Ettan IPGphor II IEF System (Amersham Biosciences) at $20{ }^{\circ} \mathrm{C}$, using a stepwise mode to reach $9000 \mathrm{Vh}$. After completion of the IEF, proteins on the strip were equilibrated in a buffer containing $6 \mathrm{M}$ urea, $130 \mathrm{mM}$ DTT, 30\% glycerol, $112 \mathrm{mM}$ Tris-base, $4 \%$ sodium dodecyl sulfate (SDS), and $0.002 \%$ bromophenol blue, for 10 min, and then with another buffer containing $6 \mathrm{M}$ urea, 135 $\mathrm{mM}$ iodoacetamide, 30\% glycerol, $112 \mathrm{mM}$ Tris-base, $4 \%$ SDS, and $0.002 \%$ bromophenol blue for $10 \mathrm{~min}$. The IPG strip was then transferred onto a $12 \%$ acrylamide slab gel $(8 \times 9.5 \mathrm{~cm})$, and the second-dimensional separation was performed in an SE260 Mini-Vertical Electrophoresis Unit (Amersham Biosciences) with the current of $20 \mu \mathrm{A} /$ gel for $1.5 \mathrm{~h}$. Separated protein spots were then visualized with Coomassie Brilliant Blue R-250 stain (Fluka Chemica AG, Buchs, Switzerland).

Spot Analysis and Matching. Image Master 2D Platinum (Amersham Biosciences) software was used for matching and analysis of protein spots on 2-D gels. Parameters used for spot detection were (i) minimal area $=10$ pixels; (ii) smooth factor $=2.0$; and (iii) saliency $=2.0$. A reference gel was created from an artificial gel combining all of the spots presenting in different gels into one image. The reference gel was then used for matching of corresponding protein spots between gels. Background subtraction was performed, and the intensity volume of each spot was normalized with total intensity volume (summation of the intensity volumes obtained from all spots 
within the same 2-D gel). The variability of the 2-D spot pattern was evaluated by determining the coefficient of variation (CV) of the normalized intensity of corresponding spots across different gels using the following formula: $\mathrm{CV}=$ Standard deviation/Mean.

In-Gel Tryptic Digestion. Differentially expressed protein spots were excised from 2-D gels, and the gel pieces were washed with $200 \mu \mathrm{L}$ of $50 \%$ acetonitrile (ACN) $/ 25 \mathrm{mM} \mathrm{NH}_{4}$ $\mathrm{HCO}_{3}$ buffer ( $\mathrm{pH}$ 8.0) for 15 min twice. The gel pieces were then washed once with $200 \mu \mathrm{L}$ of $100 \%$ ACN and dried using a Speed Vac concentrator (Savant, Holbrook, NY). Dried gel pieces were swollen with $10 \mu \mathrm{L}$ of $1 \%(\mathrm{w} / \mathrm{v})$ trypsin (Promega, Madison, WI) in $25 \mathrm{mM} \mathrm{NH}_{4} \mathrm{HCO}_{3}$. The gel pieces were then crushed with a siliconized blue stick and incubated at $37{ }^{\circ} \mathrm{C}$ for at least $16 \mathrm{~h}$. Peptides were subsequently extracted twice with $50 \mu \mathrm{L}$ of $50 \%$ ACN/5\% trifluoroacetic acid (TFA); the extracted solutions were then combined and dried with the Speed Vac concentrator. The peptide pellets were then resuspended in $10 \mu \mathrm{L}$ of $0.1 \%$ TFA, and the resuspended solutions were purified using ZipTip ${ }_{\mathrm{C} 18}$ (Millipore, Bedford, MA). Ten microliters of sample was drawn up and down in the ZipTip 10 times and then washed with $10 \mu \mathrm{L}$ of $0.1 \%$ formic acid by drawing up and expelling the washing solution three times. The peptides were finally eluted with $5 \mu \mathrm{L}$ of $75 \%$ ACN $/ 0.1 \%$ formic acid.

Protein Identification by Q-TOF MS/MS. The proteolytic samples were premixed $1: 1$ with the matrix solution $(5 \mathrm{mg} / \mathrm{mL}$ $\alpha$-cyano-4-hydroxycinnamic acid (CHCA) in $50 \% \mathrm{ACN}, 0.1 \% \mathrm{v} / \mathrm{v}$ TFA, and $2 \% \mathrm{w} / \mathrm{v}$ ammonium citrate) and spotted onto the $96-$ well sample stage. The samples were analyzed using the Q-TOF Ultima mass spectrometer (Micromass, Manchester, U.K.), which was fully automated with predefined probe motion pattern and the peak intensity threshold for switching over from MS survey scanning to MS/MS, and from one MS/MS to another. Within each sample well, parent ions that met the predefined criteria (any peak within the $\mathrm{m} / z$ 800-3000 range with intensity above 10 count \pm include/exclude list) were selected for CID MS/MS using argon as the collision gas and a mass dependent $\pm 5 \mathrm{~V}$ rolling collision energy until the end of the probe pattern was reached (all details are available at http://proteome.sinica.edu.tw). The MASCOT (http://www.matrixscience.com) search engine was used for obtaining protein identities and peptide sequences, based on the assumptions that peptides were monoisotopic, oxidized at methionine residues, and carbamidomethylated at cysteine residues. The search was performed using the entire protein databases of the Swiss-Prot and TrEMBL and MSDB. A mass tolerance of $50 \mathrm{ppm}$ was used, and up to 1 missed trypsin cleavage was allowed.

In Vivo Virulence Study. Evaluation of the virulence of RpoE Mut was performed using a pulmonary model of melioidosis in BALB/c mice as described previously. ${ }^{22}$ In summary, 1000 CFU of either K96243 WT or RpoE Mut was administered via the intranasal route ( $n=6$ per group), and the mice were then monitored twice daily for signs of infection and mortality.

Statistical Analysis. Comparisons between groups were performed using unpaired $t$ test. For the virulence study, differences in survival of the infected animals were analyzed using a log rank test. $P$-values less than 0.05 were considered statistically significant.

\section{Results and Discussion}

Validation of the rpoE Operon Knockout Mutant. Southern hybridization was performed to confirm the integration of the

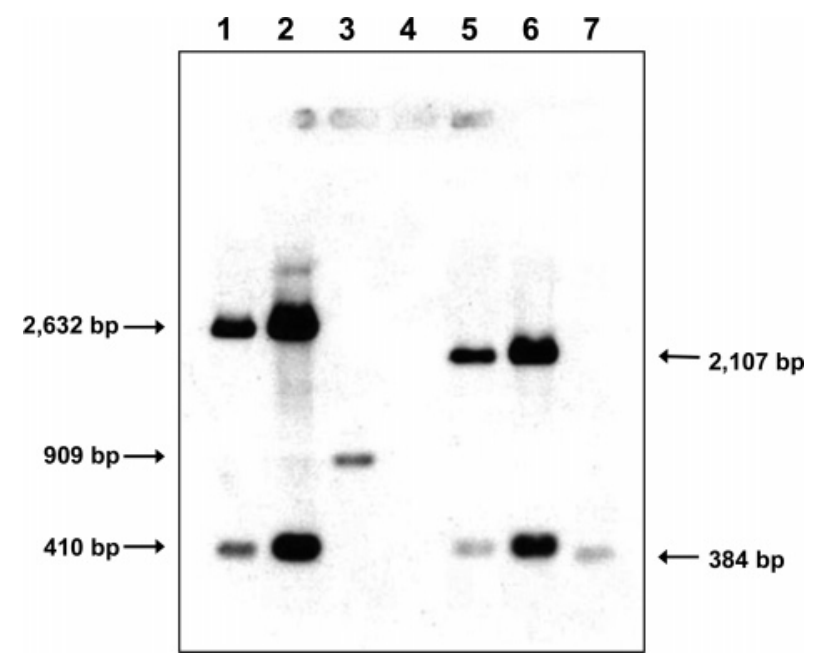

Figure 1. Southern blot analysis of digested B. pseudomallei genomic DNA hybridized with a 270-bp rpoE specific DNA probe. Lanes 1 and 2, Xhol-digested genomic DNA from RpoE Mut; lane 3, Xhol-digested genomic DNA from K96243 WT; lane 4, standard marker (1 kb DNA ladder); lanes 5 and 6, Xhol/EcoRV-digested genomic DNA from RpoE Mut; lane 7, Xhol/EcoRV-digested genomic DNA from K96243 WT.

pKNOCK suicide vector on the rpoE operon knockout mutant (RpoE Mut). The genomic DNAs from the K96243 WT and RpoE Mut of B. pseudomallei were prepared. Both genomic DNAs were digested with restriction enzymes, including XhoI and $E c o$ RV/XhoI. Southern blot of the digested genomic DNAs was hybridized with an rpoE DNA probe. As expected, one DNA hybridization fragment (909 bp) was detected in the XhoI genomic DNA of K96243 WT, whereas two DNA hybridizing fragments (2632 bp and $410 \mathrm{bp}$ ) were detected in XhoI genomic DNA of RpoE Mut (Figure 1; lanes 1-3). As also predicted, a 384 bp EcoRV/XhoI DNA fragment from K96243 WT was detected (Figure 1; lane 7), whereas $2107 \mathrm{bp}$ and $410 \mathrm{bp} \mathrm{EcoRV/}$ XhoI DNA fragments from RpoE Mut were shown (Figure 1; lanes 5 and 6). These results indicated that there was an insertion of the pKNOCK vector at the $r p o E$ gene on the chromosome of B. pseudomallei RpoE Mut.

Altered Proteome in RpoE Mut B. pseudomallei. As RpoE is a transcriptional factor, it is expected that production of several proteins (gene products) are controlled by RpoE. To explore such gene products and to further investigate the molecular mechanisms of RpoE, we performed a proteomic analysis of differentially expressed proteins in RpoE Mut compared to K96243 WT. Proteins extracted from bacteria in each cultured flask were resolved in individual 2-D gels; $n=5$ gels (from 5 cultured flasks) for each group; total $n=10$ gels. Figure 2 shows representative 2-D gels of cellular proteins extracted from K96243 WT and RpoE Mut. Up to 450 protein spots were visualized in each gel. Among these, quantitative intensity analysis and statistics revealed 52 differentially expressed protein spots (with $p<0.05$ ) between the K96243 WT and RpoE Mut groups.

These differentially expressed proteins were subsequently identified by Q-TOF MS/MS, and their identities as well as quantitative data are shown in Table 1. The amino acid sequences of peptides identified are provided in Supporting Information (Table S1). These identified proteins were classified into functional groups based on their functions provided in the Swiss-Prot and TrEMBL protein databases and on literature 

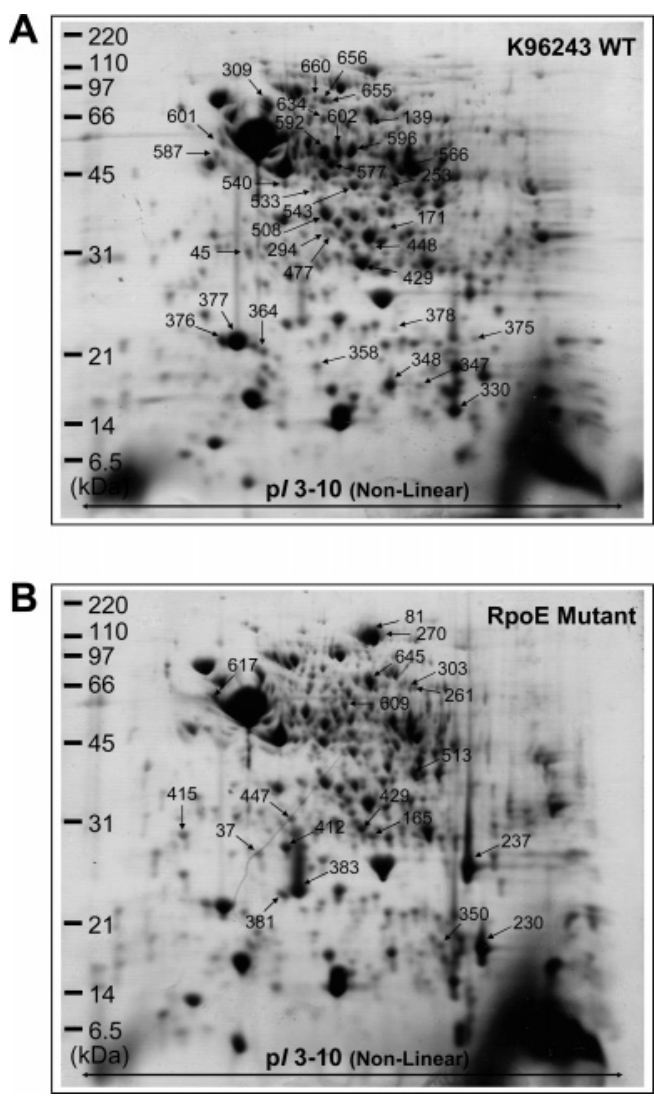

Figure 2. Proteome maps of differentially expressed proteins. (A) Representative 2-D gel for K96243 WT and (B) for RpoE Mut ( $n=5$ gels for each group; total $n=10$ ). Quantitative intensity analysis revealed 52 differentially expressed protein spots between the two groups. Down-regulated proteins are labels with numbers in panel $A$, whereas up-regulated proteins are labeled in panel B. These differentially expressed proteins were subsequently identified by Q-TOF MS/MS (see Table 1 and Supporting Information).

search in PubMed. Some of the identified proteins were 'hypothetical proteins' of which the functions are unknown or have not previously been determined. However, sequences of some of these hypothetical proteins were identical $(100 \%$ similarity) or almost identical (89-94\% similarity) to the known proteins, of which functions have been clearly defined. Therefore, these hypothetical proteins were functionally classified based on their respective homologues.

Impaired Stress Tolerance and Decreased Intracellular Survival of the rpoE Operon Knockout Mutant. Because $B$. pseudomallei is a saprophyte found in soil and can survive in eukaryotic cells as well as in phagocytes, it is expected that this bacterium must have regulatory mechanisms for adaptation in these stressful environments, particularly the enrichment of free radicals or reactive oxygen intermediates and high osmolarity. In our previous report [see Korbsrisate et al. ${ }^{17}$ ], we had examined the effects of rpoE operon knockout on the susceptibility of $B$. pseudomallei to oxidative (using $100 \mathrm{mM}$ menadione, $1 \mathrm{M} \mathrm{H}_{2} \mathrm{O}_{2}$, and $4 \mathrm{M} \mathrm{H}_{2} \mathrm{O}_{2}$ ) and osmotic stresses (using $2 \mathrm{M} \mathrm{NaCl}$ ), and evaluated the viability of RpoE Mut inside mammalian (murine) macrophages. The results clearly showed that the rpoE operon knockout caused impaired tolerance to the oxidative stress (as the zone of growth inhibition was greater in RpoE Mut compared to K96243 WT) and to the osmotic stress. ${ }^{17}$ For the intracellular survival, the viability of RpoE Mut in mammalian phagocytes was significantly reduced. ${ }^{17}$ These data indicated that the $r p o E$ operon is crucial for stress tolerance and intracellular survival of $B$. pseudomallei.

Interestingly, 16 out of 52 differentially expressed proteins identified in our present study were oxidative stress response proteins, osmotic stress response proteins, chaperones, and other stress response proteins (Table 1). Almost all of these stress response proteins were down-regulated (RpoE Mut/ K96243 WT ratios ranged from 0.24 to 0.79 ; average $=0.47$ ). The down-regulation (approximately 50\% from the baseline) of these stress associated proteins, particularly the oxidative stress response group (i.e., AhpC/Tsa family antioxidant protein, ferritin-like domain protein, flavohemoprotein, and peroxidase/catalase) and chaperones (i.e., $60 \mathrm{kDa}$ chaperonin, GroEL, heat shock protein HtpG, PspA/IM30 family protein, and universal stress protein family), in RpoE Mut was concordant with the phenotype of the rpoE operon knockout mutant, of which the stress tolerance was impaired. Osmotically inducible Y domain protein was one among the three up-regulated stress associated proteins. While it was up-regulated, the phenotype of RpoE Mut showed impaired osmotic stress tolerance. These disparate results were not surprising as osmotic stress in several other models can be regulated by various chaperones and other stress associated proteins, ${ }^{23-25}$ some of which were down-regulated in our present study (Table 1). These data strengthened the information that the rpoE operon is required for stress tolerance in B. pseudomallei via controlling transcription/translation of various stress associated proteins.

Other groups of the differentially expressed proteins were transcriptional/translational regulators and proteins involved in cell wall synthesis. Almost all of these altered proteins were down-regulated or absent (or might be under the detection limit of our experimental procedures) in RpoE Mut. The downregulation of these two groups of proteins together with the down-regulation of several stress response proteins, as mentioned above, most likely led to the decreased survival of RpoE Mut in mammalian (murine) phagocytes. ${ }^{17}$

There were a few groups of proteins (i.e., metabolic enzymes and exported proteins) in which the number of the upregulated proteins was comparable to that of the downregulated proteins within the same group. This pattern of changes implicates that there was a balance between the upregulations and the down-regulations, similar to changes almost always observed in several other models of experimental interventions or gene manipulation in our previous studies. ${ }^{26-30}$ Further examination of their roles and association with RpoE is required to better understand the functional significance of these altered proteins in B. pseudomallei.

Impaired Virulence of the rpoE Operon Knockout Mutant. Potential virulence factors of $B$. pseudomallei (which include both well-known and possible ones) are secretion type I-IV systems, surface components (i.e., lipopolysaccharide, capsular polysaccharide, and potential surface polysaccharide biosynthesis), fimbriae/pili, exoproteins (phospholipase C, metalloproteases A, collagenase, and other proteases), and adhesins or adhesive molecules that modulate host-cell interaction. ${ }^{3,18}$ In the present study, we identified the down-regulation of a protease/peptidase (serine-type carboxypeptidase family protein; spot no. 634) and of an adhesion molecule (phospholipidbinding protein; spot no. 364) (Table 1) that may be the potential virulence factors of $B$. pseudomallei. Although there is no direct evidence demonstrating that carboxypeptidase is 
Table 1. The Altered Proteins in RpoE Mut

\begin{tabular}{|c|c|c|c|c|c|c|c|c|c|c|c|}
\hline \multirow[b]{2}{*}{ altered proteins } & \multirow[b]{2}{*}{$\begin{array}{c}\text { spot } \\
\text { no. }\end{array}$} & \multicolumn{2}{|c|}{ Quantity (Intensity) (Mean \pm SEM) } & \multirow[b]{2}{*}{$p$} & \multirow[b]{2}{*}{$\begin{array}{c}\text { ratio } \\
\text { (Mut/WT) }\end{array}$} & \multirow[b]{2}{*}{ change } & \multirow[b]{2}{*}{ ID } & \multirow[b]{2}{*}{$\begin{array}{l}\text { ion } \\
\text { score }\end{array}$} & \multirow[b]{2}{*}{$\% \operatorname{cov}$} & \multirow[b]{2}{*}{$\mathrm{p} I$} & \multirow[b]{2}{*}{ MW } \\
\hline & & K96243 WT & RpoE Mut & & & & & & & & \\
\hline \multicolumn{12}{|c|}{ Oxidative Stress Response Proteins } \\
\hline $\begin{array}{l}\text { Antioxidant, AhpC/Tsa family } \\
{\text { [Burkholderia mallei }]^{a}}\end{array}$ & 376 & $0.5071 \pm 0.0466$ & $0.2176 \pm 0.0311$ & 0.001 & 0.43 & Down & Q62JI8_BURMA & 197 & 31 & 5.1 & 20.46 \\
\hline 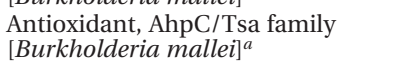 & 377 & $2.6473 \pm 0.4435$ & $1.3248 \pm 0.1059$ & 0.020 & 0.50 & Down & Q62JI8_BURMA & 187 & 31 & 5.1 & 20.46 \\
\hline $\begin{array}{l}\text { Antioxidant, AhpC/Tsa family } \\
{\text { [Burkholderia mallei }]^{a}}\end{array}$ & 429 & $0.8098 \pm 0.0580$ & $0.3810 \pm 0.0662$ & 0.001 & 0.47 & Down & Q62I24_BURMA & 294 & 30 & 5.8 & 23.90 \\
\hline $\begin{array}{l}\text { Ferritin-like domain protein } \\
\text { [Burkholderia mallei] }\end{array}$ & 348 & $1.1054 \pm 0.0998$ & $0.6615 \pm 0.0450$ & 0.004 & 0.60 & Down & Q62H71_BURMA & 153 & 22 & 6.0 & 18.14 \\
\hline $\begin{array}{l}\text { Flavohemoprotein [Burkholderia } \\
\text { pseudomallei] }\end{array}$ & 566 & $0.2350 \pm 0.0156$ & $0.1357 \pm 0.0061$ & $<0.001$ & 0.58 & Down & Q63R34_BURPS & 157 & 16 & 6.1 & 43.64 \\
\hline $\begin{array}{l}\text { Peroxidase/catalase (EC 1.11.1.6 } \\
\text { (Catalase-peroxidase) } \\
\text { [Burkholderia mallei] }\end{array}$ & 655 & $0.0832 \pm 0.0089$ & $0.0227 \pm 0.0095$ & 0.002 & 0.27 & Down & Q62H74_BURMA & 248 & 6 & 5.7 & 79.45 \\
\hline $\begin{array}{l}\text { Putative phenylacetic acid } \\
\text { degradation oxidoreductase }\end{array}$ & 645 & $0.6072 \pm 0.0358$ & $0.7921 \pm 0.0618$ & 0.032 & 1.30 & Up & Q63QI2_BURPS & 335 & 10 & 5.9 & 60.85 \\
\hline \multicolumn{12}{|c|}{ Osmotic Stress Response Proteins } \\
\hline $\begin{array}{l}\text { Osmotically inducible protein Y } \\
\text { domain protein [Burkholderia } \\
\text { mallei] }\end{array}$ & 412 & $0.2610 \pm 0.0387$ & $0.3757 \pm 0.0211$ & 0.032 & 1.44 & Up & Q62E87_BURMA & 135 & 12 & 5.3 & 23.15 \\
\hline \multicolumn{12}{|c|}{ Other Stress Response Proteins } \\
\hline $\begin{array}{l}60 \mathrm{kDa} \text { chaperonin [Burkholderia } \\
\text { pseudomallei K96243] }\end{array}$ & 601 & $0.3586 \pm 0.0571$ & $0.1402 \pm 0.0121$ & 0.006 & 0.39 & Down & САH36705 & 157 & 10 & 5.1 & 57.14 \\
\hline $\begin{array}{l}\text { GroEL (Fragment) [Burkholderia } \\
\text { pseudomallei] }\end{array}$ & 540 & $0.1241 \pm 0.0093$ & $0.0572 \pm 0.0049$ & $<0.001$ & 0.46 & Down & Q83WK0_BURPS & 195 & 10 & 5.2 & 56.49 \\
\hline $\begin{array}{l}\text { GroEL (Fragment) [Burkholderia } \\
\text { pseudomallei] }\end{array}$ & 577 & $0.2034 \pm 0.0154$ & $0.0996 \pm 0.0109$ & 0.001 & 0.49 & Down & Q83WK0_BURPS & 175 & 10 & 5.2 & 56.49 \\
\hline $\begin{array}{l}\text { GroEL (Fragment) [Burkholderia } \\
\text { pseudomallei] }\end{array}$ & 587 & $0.1323 \pm 0.0202$ & $0.0410 \pm 0.0048$ & 0.002 & 0.31 & Down & Q83WK0_BURPS & 190 & 10 & 5.2 & 56.49 \\
\hline $\begin{array}{l}\text { Heat shock protein HtpG } \\
\text { [Burkholderia mallei] }\end{array}$ & 309 & $0.9076 \pm 0.0816$ & $0.6645 \pm 0.0665$ & 0.049 & 0.73 & Down & Q62ID1_BURMA & 274 & 14 & 5.1 & 71.22 \\
\hline $\begin{array}{l}\text { PspA/IM30 family protein (phage } \\
\text { shock protein A) (suppresses } \\
\text { sigma54-dependent transcription) } \\
\text { [Burkholderia mallei] }\end{array}$ & 45 & $0.2709 \pm 0.0174$ & $0.2152 \pm 0.0072$ & 0.018 & 0.79 & Down & Q62JH7_BURMA & 100 & 18 & 5.1 & 24.48 \\
\hline $\begin{array}{l}\text { Trigger factor (EC 5.2.1.8) } \\
\text { [Burkholderia mallei] }\end{array}$ & 617 & $0.2335 \pm 0.0191$ & $0.4046 \pm 0.0418$ & 0.006 & 1.73 & Up & Q62JK6_BURMA & 38 & 6 & 5.0 & 49.71 \\
\hline $\begin{array}{l}\text { Universal stress protein family } \\
\text { [Burkholderia mallei] }\end{array}$ & 340 & $0.2697 \pm 0.0095$ & $0.0647 \pm 0.0066$ & $<0.001$ & 0.24 & Down & Q62EI9_BURMA & 320 & 44 & 5.8 & 16.62 \\
\hline \multicolumn{12}{|c|}{ Transcriptional/Translational Regulators } \\
\hline $\begin{array}{l}\text { Adenosylhomocysteinase } \\
\text { [Burkholderia pseudomallei } \\
\text { K96243] }\end{array}$ & 596 & $0.5861 \pm 0.0413$ & $0.3618 \pm 0.0269$ & 0.002 & 0.62 & Down & САH37303 & 140 & 7 & 5.7 & 52.51 \\
\hline $\begin{array}{l}\text { Adenosylhomocysteinase } \\
\text { [Burkholderia pseudomallei } \\
\text { K96243] }\end{array}$ & 602 & $0.4094 \pm 0.0555$ & $0.1955 \pm 0.0383$ & 0.013 & 0.48 & Down & САH37303 & 186 & 11 & 5.7 & 52.51 \\
\hline $\begin{array}{l}\text { Arginine deiminase [Burkholderia } \\
\text { pseudomallei K96243] }\end{array}$ & 592 & $0.7188 \pm 0.0774$ & $0.3946 \pm 0.0434$ & 0.006 & 0.55 & Down & СAH35742 & 273 & 16 & 5.6 & 46.42 \\
\hline $\begin{array}{l}\text { DNA-directed RNA polymerase } \\
\text { alpha chain [Burkholderia } \\
\text { pseudomallei K96243] }\end{array}$ & 543 & $0.3397 \pm 0.0050$ & $0.3037 \pm 0.0064$ & 0.002 & 0.89 & Down & САН37198 & 295 & 26 & 5.8 & 35.78 \\
\hline $\begin{array}{l}\text { Endoribonuclease, L-PSP family } \\
\text { [Burkholderia mallei] }\end{array}$ & 347 & $0.1282 \pm 0.0075$ & $0.0850 \pm 0.0055$ & 0.002 & 0.66 & Down & Q62HN3_BURMA & 122 & 22 & 6.2 & 15.95 \\
\hline $\begin{array}{l}\text { Hypothetical protein } \text { [Burkholderia }_{\text {pseudomallei }^{b}} \\
\end{array}$ & 237 & $1.3144 \pm 0.1586$ & $3.0324 \pm 0.2261$ & $<0.001$ & 2.31 & Up & Q63NT6_BURPS & 119 & 16 & 6.7 & 21.65 \\
\hline $\begin{array}{l}\text { Putative methyltransferase } \\
\text { [Burkholderia pseudomallei] }\end{array}$ & 448 & $0.0540 \pm 0.0137$ & $0.0000 \pm 0.0000$ & 0.004 & 0.00 & Absent & Q63L99_BURPS & 155 & 18 & 5.9 & 29.52 \\
\hline $\begin{array}{l}\text { Ribonuclease PH [Burkholderia } \\
\text { pseudomallei] }\end{array}$ & 171 & $0.0926 \pm 0.0109$ & $0.0571 \pm 0.0095$ & 0.040 & 0.62 & Down & САН36573 & 51 & 4 & 6.0 & 26.21 \\
\hline $\begin{array}{l}\text { Transcriptional regulator, AsnC } \\
\text { family [Burkholderia mallei] }\end{array}$ & 350 & $0.0392 \pm 0.0025$ & $0.1066 \pm 0.0248$ & 0.027 & 2.72 & Up & Q62M96_BURMA & 63 & 11 & 6.5 & 19.08 \\
\hline $\begin{array}{l}\text { YbaK/prolyl-tRNA } \\
\text { synthetases-associated domain }\end{array}$ & 358 & $0.1446 \pm 0.0096$ & $0.0758 \pm 0.0080$ & 0.001 & 0.52 & Down & Q62C75_BURMA & 159 & 21 & 5.5 & 18.14 \\
\hline \multicolumn{12}{|c|}{ Metabolic Enzymes } \\
\hline $\begin{array}{l}\text { 3-Oxoadipate CoA-succinyl } \\
\text { transferase beta subunit } \\
\text { [Burkholderia mallei] }\end{array}$ & 415 & $0.0749 \pm 0.0078$ & $0.2232 \pm 0.0343$ & 0.003 & 2.98 & Up & Q62KH2_BURMA & 236 & 23 & 4.7 & 22.33 \\
\hline $\begin{array}{l}\text { Aldehyde dehydrogenase family } \\
\text { protein [Burkholderia mallei] }\end{array}$ & 609 & $0.1036 \pm 0.0128$ & $0.2361 \pm 0.0371$ & 0.010 & 2.28 & Up & Q62FN8_BURMA & 235 & 16 & 5.7 & 55.72 \\
\hline $\begin{array}{l}\text { Carbamate kinase (EC 2.7.2.2) } \\
\text { [Burkholderia pseudomallei] }\end{array}$ & 508 & $0.5604 \pm 0.0263$ & $0.4655 \pm 0.0098$ & 0.010 & 0.83 & Down & Q63U71_BURPS & 225 & 17 & 5.5 & 33.51 \\
\hline $\begin{array}{l}\text { GMP synthase } \\
\text { [glutamine-hydrolyzing] (EC } \\
\text { 6.3.5.2) [Burkholderia } \\
\text { pseudomallei] }\end{array}$ & 139 & $0.0845 \pm 0.0056$ & $0.0063 \pm 0.0063$ & $<0.001$ & 0.07 & Down & Q63T42_BURPS & 196 & 11 & 5.9 & 60.48 \\
\hline $\begin{array}{l}\text { Spermidine } \mathrm{n}(1) \text {-acetyltransferase } \\
\text { (EC 2.3.1.57) [Burkholderia } \\
\text { pseudomallei] }\end{array}$ & 378 & $0.0699 \pm 0.0098$ & $0.0000 \pm 0.0000$ & $<0.001$ & 0.00 & Absent & Q63YU3_BURPS & 169 & 14 & 5.9 & 22.22 \\
\hline $\begin{array}{l}\text { Urocanate hydratase (EC 4.2.1.49) } \\
\text { [Burkholderia mallei] }\end{array}$ & 261 & $0.0717 \pm 0.0042$ & $0.1054 \pm 0.0055$ & 0.001 & 1.47 & Up & Q62LJ4_BURMA & 125 & 6 & 6.1 & 61.86 \\
\hline $\begin{array}{l}\text { Urocanate hydratase (EC 4.2.1.49) } \\
\text { [Burkholderia mallei] }\end{array}$ & 303 & $0.0535 \pm 0.0079$ & $0.0849 \pm 0.0082$ & 0.025 & 1.59 & Up & Q62LJ4_BURMA & 297 & 11 & 6.1 & 61.86 \\
\hline
\end{tabular}


Table 1 (Continued)

\begin{tabular}{|c|c|c|c|c|c|c|c|c|c|c|c|}
\hline \multirow[b]{2}{*}{ altered proteins } & \multirow{2}{*}{$\begin{array}{l}\text { spot } \\
\text { no. }\end{array}$} & \multicolumn{2}{|c|}{ Quantity (Intensity) (Mean \pm SEM) } & \multirow[b]{2}{*}{$p$} & \multirow{2}{*}{$\begin{array}{c}\text { ratio } \\
\text { (Mut/WT) }\end{array}$} & \multirow[b]{2}{*}{ change } & \multirow[b]{2}{*}{ ID } & \multirow{2}{*}{$\begin{array}{l}\text { ion } \\
\text { score }\end{array}$} & \multirow[b]{2}{*}{$\% \operatorname{cov}$} & \multirow[b]{2}{*}{$\mathrm{p} I$} & \multirow[b]{2}{*}{ MW } \\
\hline & & K96243 WT & RpoE Mut & & & & & & & & \\
\hline \multicolumn{12}{|c|}{ Cell Wall Synthesis Pathway } \\
\hline $\begin{array}{l}\text { Glucose-1-phosphate } \\
\text { thymidylyltransferase (EC 2.7.7.24) } \\
\text { (dTDP-glucose pyrophosphorylase) } \\
\text { (dTDP-glucose synthase) } \\
\text { [Burkholderia mallei] }\end{array}$ & 477 & $0.1201 \pm 0.0095$ & $0.0742 \pm 0.0033$ & 0.002 & 0.62 & Down & Q9AEV6_BURMA & 51 & 6 & 5.6 & 33.07 \\
\hline $\begin{array}{l}\text { Putative dTDP-D-glucose 4, } \\
\text { 6-dehydratase (EC 4.2.1.46) } \\
\text { [Burkholderia pseudomallei] }\end{array}$ & 253 & $0.1977 \pm 0.0178$ & $0.1521 \pm 0.0059$ & 0.041 & 0.77 & Down & Q9AEV7_BURPS & 127 & 7 & 6.0 & 39.34 \\
\hline \multicolumn{12}{|c|}{ Glycogen Biosynthesis and Storage Pathway } \\
\hline $\begin{array}{l}\text { Inorganic pyrophosphatase (EC } \\
\text { 3.6.1.1) [Burkholderia mallei] }\end{array}$ & 381 & $0.2477 \pm 0.0067$ & $0.4036 \pm 0.0300$ & 0.001 & 1.63 & Up & Q62LB4_BURMA & 42 & 17 & 5.2 & 19.26 \\
\hline \multicolumn{12}{|c|}{ Fatty Acid Synthesis } \\
\hline $\begin{array}{l}\text { Putative beta-ketoacyl-ACP } \\
\text { synthase [Burkholderia } \\
\text { pseudomallei] }\end{array}$ & 533 & $0.1011 \pm 0.0062$ & $0.0573 \pm 0.0019$ & $<0.001$ & 0.57 & Down & Q63N14_BURPS & 96 & 10 & 5.4 & 40.75 \\
\hline \multicolumn{12}{|c|}{ Exported Proteins } \\
\hline $\begin{array}{l}\text { Putative exported protein } \\
{[\text { Burkholderia pseudomallei }]}\end{array}$ & 330 & $1.2433 \pm 0.0680$ & $0.9420 \pm 0.0898$ & 0.028 & 0.76 & Down & Q63VW9_BURPS & 110 & 59 & 9.2 & 13.75 \\
\hline $\begin{array}{l}\text { Putative porin related exported } \\
\text { protein [Burkholderia pseudomallei] }\end{array}$ & 513 & $0.0619 \pm 0.0099$ & $0.3803 \pm 0.0648$ & 0.001 & 6.14 & Up & Q63JN8_BURPS & 188 & 15 & 7.8 & 40.14 \\
\hline \multicolumn{12}{|c|}{ Secreted Proteins } \\
\hline 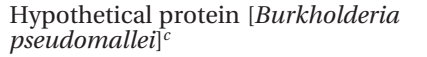 & 447 & $0.0595 \pm 0.0014$ & $0.1156 \pm 0.0079$ & $<0.001$ & 1.94 & Up & Q63IV8_BURPS & 177 & 22 & 5.3 & 23.46 \\
\hline \multicolumn{12}{|c|}{ Adhesion Molecule } \\
\hline 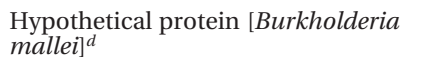 & 364 & $0.1374 \pm 0.0121$ & $0.1078 \pm 0.0043$ & 0.050 & 0.78 & Down & Q62FL1_BURMA & 274 & 33 & 5.3 & 18.34 \\
\hline \multicolumn{12}{|c|}{ Protease/Peptidase } \\
\hline $\begin{array}{l}\text { Serine-type carboxypeptidase } \\
\text { family protein [Burkholderia mallei] }\end{array}$ & 634 & $0.1359 \pm 0.0104$ & $0.0730 \pm 0.0062$ & 0.001 & 0.54 & Down & Q62AX8_BURMA & 224 & 14 & 5.6 & 60.18 \\
\hline \multicolumn{12}{|c|}{ Protease Inhibitors } \\
\hline \multicolumn{12}{|c|}{ Signaling Proteins } \\
\hline $\begin{array}{l}\text { Hypothetical protein }[\text { Burkholderia } \\
{\text { pseudomallei }]^{e}}\end{array}$ & 656 & $0.1637 \pm 0.0064$ & $0.0805 \pm 0.0016$ & $<0.001$ & 0.49 & Down & Q63TY9_BURPS & 101 & 5 & 5.5 & 73.72 \\
\hline $\begin{array}{l}\text { Hypothetical protein } \text { [Burkholderia }_{\text {pseudomallei }]^{e}} \\
\text { a }\end{array}$ & 660 & $0.0516 \pm 0.0043$ & $0.0179 \pm 0.0079$ & 0.006 & 0.35 & Down & Q63TY9_BURPS & 118 & 7 & 5.5 & 73.72 \\
\hline \multicolumn{12}{|c|}{ Miscellaneous and Unknown Function } \\
\hline $\begin{array}{l}\text { Chitin binding protein, putative } \\
\text { [Burkholderia pseudomallei] }\end{array}$ & 165 & $0.1212 \pm 0.0344$ & $0.2440 \pm 0.0327$ & 0.032 & 2.01 & Up & Q63PN3_BURPS & 66 & 11 & 6.2 & 25.89 \\
\hline $\begin{array}{l}\text { Hypothetical bacteriophage protein } \\
\text { [Burkholderia pseudomallei] }\end{array}$ & 230 & $1.0938 \pm 0.1523$ & $2.5481 \pm 0.2037$ & $<0.001$ & 2.33 & Up & Q63LD3_BURPS & 313 & 40 & 8.4 & 19.48 \\
\hline $\begin{array}{l}\text { Hypothetical protein [Burkholderia } \\
\text { pseudomallei }]^{f}\end{array}$ & 294 & $0.0998 \pm 0.0020$ & $0.0796 \pm 0.0067$ & 0.021 & 0.80 & Down & Q63KM8_BURPS & 132 & 15 & 5.6 & 31.14 \\
\hline $\begin{array}{l}\text { Hypothetical protein [Burkholderia } \\
\text { pseudomallei] }\end{array}$ & 37 & $0.1138 \pm 0.0277$ & $0.2363 \pm 0.0215$ & 0.008 & 2.08 & Up & Q63UP7_BURPS & 285 & 37 & 5.1 & 23.38 \\
\hline $\begin{array}{l}\text { Hypothetical protein [Burkholderia } \\
\text { pseudomallei] }\end{array}$ & 81 & $0.8615 \pm 0.0449$ & $1.8358 \pm 0.0917$ & $<0.001$ & 2.13 & Up & Q63KK6_BURPS & 224 & 6 & 5.9 & 124.63 \\
\hline $\begin{array}{l}\text { Hypothetical protein [Burkholderia } \\
\text { pseudomallei] }\end{array}$ & 270 & $0.0857 \pm 0.0155$ & $0.1621 \pm 0.0198$ & 0.016 & 1.89 & Up & Q63KK6_BURPS & 279 & 7 & 5.9 & 124.63 \\
\hline $\begin{array}{l}\text { Hypothetical protein [Burkholderia } \\
\text { pseudomallei] }\end{array}$ & 383 & $0.6012 \pm 0.0935$ & $1.7693 \pm 0.2578$ & 0.003 & 2.94 & Up & Q63NT7_BURPS & 90 & 16 & 5.3 & 22.45 \\
\hline
\end{tabular}

${ }^{a}$ Protein is $100 \%$ identical to peroxiredoxin (gi|67763109; ZP_00501806). ${ }^{b}$ Protein is $94 \%$ identical to methylase of polypeptide chain release factors (gi|67760879; ZP_00499595). ${ }^{c}$ Protein is $89 \%$ identical to predicted periplasmic or secreted lipoprotein [Burkholderia pseudomallei S13] (gi|67762369; ZP_00501070). ${ }^{d}$ Protein is $91 \%$ identical to phospholipid-binding protein [Burkholderia pseudomallei S13] (gi|67760526; ZP_00499246). ${ }^{e}$ Protein is $100 \%$ identical to putative Ser protein kinase [Burkholderia pseudomallei S13] (gi|67758379; ZP_00497148). ${ }^{f}$ Protein is 100\% identical to O-methyltransferase involved in polyketide biosynthesis [Burkholderia pseudomallei Pasteur] (gi|67754005; ZP_00492924).

a virulence factor of $B$. pseudomallei, several lines of references have demonstrated its potential role in the virulence of Naegleria fowleri, ${ }^{31}$ Porphyromonas gingivalis, ${ }^{32,33}$ Brucella abortus, ${ }^{34}$ ans so forth. Similarly, there are some indirect evidence demonstrating that proteins with a phospholipidbinding domain may play role in the virulence of bacteria. ${ }^{35-38}$

On the basis of these data, we therefore hypothesized that the rpoE operon is also involved in the virulence of $B$. pseudomallei. An in vivo experiment was performed to address whether rpoE operon knockout affects the virulence of $B$. pseudomallei (Figure 3). All mice challenged with K96243 WT ( $n=6$ ) succumbed within 7 days, whereas all RpoE Mut infected mice $(n=6)$ survived for the duration of the experiment (terminated at 40 days; $p<0.002$ ). At this time, no bacteria were detected in the spleen or lungs of the RpoE Mut infected mice (limit of detection $\leq 100 \mathrm{CFU} /$ organ), suggesting that this mutant is severely attenuated in vivo. The decreased virulence of the RpoE Mut was probably due to the downregulation of potential virulence factors and also from the down-regulation of several various stress response proteins, as well as transcriptional/translational regulators and proteins involved in cell wall synthesis, all of which are very important for the bacteria to survive in the host. These novel findings underline the usefulness of proteomics as a screening tool to generate a new hypothesis from a set of candidate proteins that can finally be confirmed by conventional functional methods.

Technical Concerns. Some technical issues in the present study need to be discussed. First, there are four genes in the B. pseudomallei rpoE operon, including rpoE, bprE, rseB, and $m u c D$, making the rpoE operon a four-gene cluster type. In 


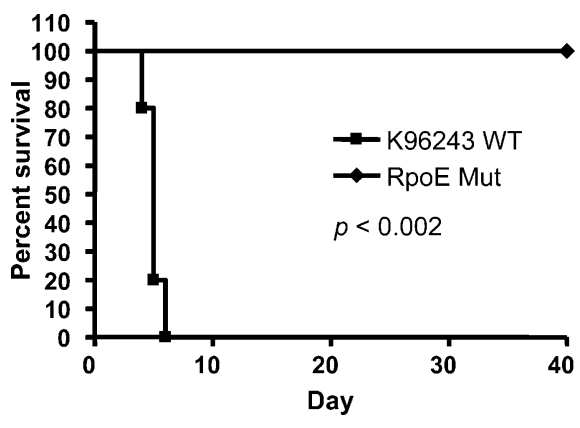

Figure 3. Impaired virulence of $r p o E$ operon knockout mutant (RpoE Mut). BALB/c mice (6 per group) were infected intranasally with $1000 \mathrm{cfu}$ of K96243 WT or RpoE Mut, and the survival of the infected mice was monitored.

the present study, we generated an rpoE operon knockout mutant. Therefore, the effects of this knockout on the other three genes could also contribute to the altered proteome observed in the present study.

Second, we examined the altered proteome of RpoE Mut only at the stationary phase. Analysis of the altered proteins at the other growth phases should provide more complete information of the molecular mechanisms of the $r p o E$ operon in $B$. pseudomallei.

Third, we examined only the cellular proteins of $B$. pseudomallei in the present study. As we identified a periplasmic or secreted lipoprotein as one of the altered proteins, we believe that the production of other secreted proteins is also regulated by the rpoE operon. Hence, proteomic analysis of proteins secreted into the culture medium is of potential interest.

Fourth, the total number of protein spots visualized in each gel in the present study was relatively small for cellular proteins extracted from a bacterium. This limitation might be due to the gel-size and staining used in the present study. Many more spots should have been detected using the larger format 2-D gel and a more sensitive stain (i.e., silver or fluorescence).

Finally, we performed proteomic analysis of cellular proteins obtained from 10 different cultures to address the reproducibility and comparability of 2-D spot patterns across different gels, one of the most important issues in gel-based, differential proteomics studies. We calculated the coefficient of variation (CV) on selected spots (nos. 364, 376, and 377) across different gels. Figure 4 illustrates such selected areas and demonstrates the CVs of individual spots that ranged from 0.08 to 0.37 within the K96243 WT or RpoE Mut groups. When all these 3 spots were considered together, the CVs were reduced to 0.29 and 0.13 for K96243 WT and RpoE Mut groups, respectively. Moreover, when all spots detected in each gel were evaluated together, the CVs were only 0.0029 for K96243 WT and 0.0056 for RpoE Mut group. The CVs in our present study were in acceptable ranges of CVs previously observed in standard, gelbased, differential proteomics studies for analyzing tissues, cell lines, and body fluids. ${ }^{30,39-41}$ In addition, the summation of normalized intensity volumes of all spots detected in each 2-D gel was comparable between the two different groups. Therefore, quantitative intensity analysis in our present study was justified.

\section{Conclusions}

We have identified a number of B. pseudomallei cellular proteins that were altered in an rpoE operon knockout mutant using proteomic technology. The down-regulation of several

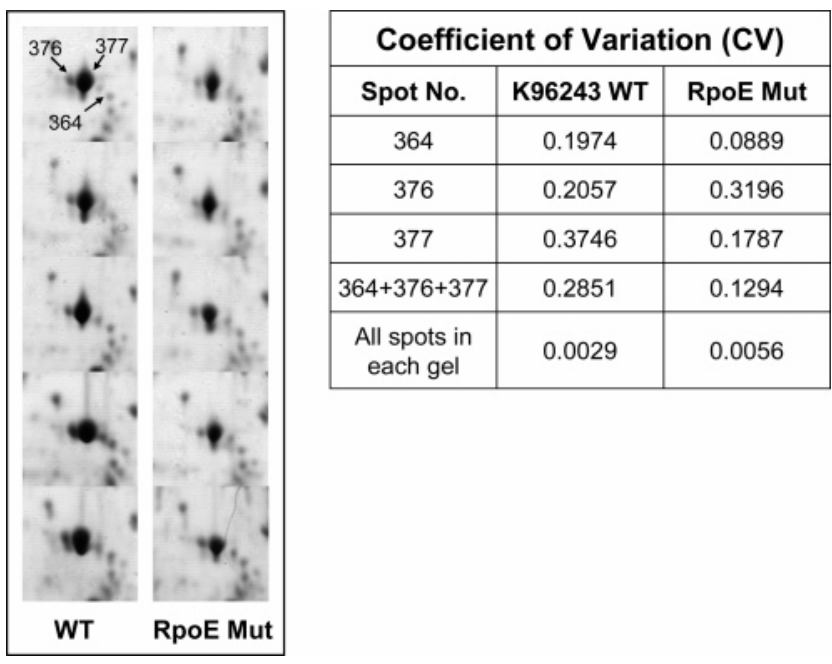

Figure 4. Reproducibility and variability of gel-based proteomics approach. Coefficients of variation (CVs) of selected spots were obtained using the formula [CV $=\mathrm{SD} /$ Mean]. The results show that CVs in our present study were in acceptable ranges of CVs previously detected in standard, gel-based, differential proteomics studies analyzing human tissues, cell lines, and body fluids. ${ }^{30,39-41}$

stress response proteins, chaperones, transcriptional/translational regulators, and proteins involved in cell wall synthesis in this mutant provided some new insights into the mechanisms of rpoE operon for stress tolerance and survival of $B$. pseudomallei. In addition to the stress tolerance and survival, the proteomic data and in vivo study indicated that the rpoE operon is also involved in the virulence of $B$. pseudomallei in the mammalian host.

Abbreviations: 2-DE, two-dimensional electrophoresis; ACN, acetonitrile; CHAPS, 3-[(3-cholamidopropyl)dimethylamino]1-propanesulfonate; CHCA, $\alpha$-cyano-4-hydroxycinnamic acid; $\mathrm{CV}$, coefficient of variation; DTT, dithiothreitol; IEF, isoelectric focusing; K96243 WT, B. pseudomallei wild-type; MN, menadione; Q-TOF MS/MS, quadrupole time-of-flight tandem mass spectrometry; RpoE, sigma factor $\sigma^{\mathrm{E}}$; RpoE Mut, rpoE operon knockout mutant of B. pseudomallei; SDS, sodium dodecyl sulfate; TFA, trifluoroacetic acid

Acknowledgment. We thank Drs. Pattarachai Kiratisin, Paiboon Vattanaviboon, and Ganjana Lertmemongkolchai for their valuable advice, and are grateful to Jon Cuccui for his assistance in verifying the mutant line for the in vivo study. This study was supported by Siriraj Grant for Research and Development, Commission on Higher Education, and The Thailand Research Fund (Grant RMU 5080015) to S. Korbsrisate and V. Thongboonkerd. M. Vanaporn was supported by the Royal Golden Jubilee Ph.D. Program (PHD/0044/2545).

Supporting Information Available: Table listing the sequences of the identified peptides using Q-TOF MS/MS. This material is available free of charge via the Internet at http:// pubs.acs.org.

\section{References}

(1) Leelarasamee, A. Recent development in melioidosis. Curr. Opin. Infect. Dis. 2004, 17, 131-136.

(2) White, N. J. Melioidosis. Lancet 2003, 361, 1715-1722.

(3) Cheng, A. C.; Currie, B. J. Melioidosis: epidemiology, pathophysiology, and management. Clin. Microbiol. Rev. 2005, 18, 383416. 
(4) Ades, S. E. Control of the alternative sigma factor sigmaE in Escherichia coli. Curr. Opin. Microbiol. 2004, 7, 157-162.

(5) Moreno, S.; Najera, R.; Guzman, J.; Soberon-Chavez, G.; Espin, G. Role of alternative sigma factor algU in encystment of Azotobacter vinelandii. J. Bacteriol. 1998, 180, 2766-2769.

(6) Martinez-Salazar, J. M.; Moreno, S.; Najera, R.; Boucher, J. C.; Espin, G.; Soberon-Chavez, G.; Deretic, V. Characterization of the genes coding for the putative sigma factor $\mathrm{AlgU}$ and its regulators MucA, MucB, MucC, and MucD in Azotobacter vinelandii and evaluation of their roles in alginate biosynthesis. J. Bacteriol. 1996 $178,1800-1808$.

(7) Henriques, A. O.; Beall, B. W.; Roland, K.; Moran, C. P., Jr. Characterization of cotJ, a sigma E-controlled operon affecting the polypeptide composition of the coat of Bacillus subtilis spores. J. Bacteriol. 1995, 177, 3394-3406.

(8) Shazand, K.; Frandsen, N.; Stragier, P. Cell-type specificity during development in Bacillus subtilis: the molecular and morphological requirements for sigma E activation. EMBO J. 1995, 14, 14391445.

(9) Craig, J. E.; Nobbs, A.; High, N. J. The extracytoplasmic sigma factor, final sigma(E), is required for intracellular survival of nontypeable Haemophilus influenzae in J774 macrophages. Infect. Immun. 2002, 70, 708-715.

(10) Manganelli, R.; Fattorini, L.; Tan, D.; Iona, E.; Orefici, G.; Altavilla G.; Cusatelli, P.; Smith, I. The extra cytoplasmic function sigma factor sigma(E) is essential for Mycobacterium tuberculosis virulence in mice. Infect. Immun. 2004, 72, 3038-3041.

(11) Hershberger, C. D.; Ye, R. W.; Parsek, M. R.; Xie, Z. D.; Chakrabarty, A. M. The algT (algU) gene of Pseudomonas aeruginosa, a key regulator involved in alginate biosynthesis, encodes an alternative sigma factor (sigma E). Proc. Natl. Acad. Sci. U.S.A. 1995, 92, 7941-7945.

(12) Schurr, M. J.; Yu, H.; Boucher, J. C.; Hibler, N. S.; Deretic, V. Multiple promoters and induction by heat shock of the gene encoding the alternative sigma factor AlgU (sigma E) which controls mucoidy in cystic fibrosis isolates of Pseudomonas aeruginosa. J. Bacteriol. 1995, 177, 5670-5679.

(13) Schnider-Keel, U.; Lejbolle, K. B.; Baehler, E.; Haas, D.; Keel, C. The sigma factor AlgU (AlgT) controls exopolysaccharide production and tolerance towards desiccation and osmotic stress in the biocontrol agent Pseudomonas fluorescens CHA0. Appl. Environ. Microbiol. 2001, 67, 5683-5693.

(14) Kenyon, W. J.; Sayers, D. G.; Humphreys, S.; Roberts, M.; Spector, M. P. The starvation-stress response of Salmonella enterica serovar Typhimurium requires sigma(E)-, but not CpxR-regulated extracytoplasmic functions. Microbiology 2002, 148, 113-122.

(15) Bralley, P.; Jones, G. H. Transcriptional analysis and regulation of the sigma-E gene of Streptomyces antibioticus. Biochim. Biophys. Acta 2001, 1517, 410-415.

(16) Kovacikova, G.; Skorupski, K. The alternative sigma factor sigma(E) plays an important role in intestinal survival and virulence in Vibrio cholerae. Infect. Immun. 2002, 70, 5355-5362.

(17) Korbsrisate, S.; Vanaporn, M.; Kerdsuk, P.; Kespichayawattana, W.; Vattanaviboon, P.; Kiatpapan, P.; Lertmemongkolchai, G. The Burkholderia pseudomallei RpoE (AlgU) operon is involved in environmental stress tolerance and biofilm formation. FEMS Microbiol. Lett. 2005, 252, 243-249.

(18) Holden, M. T.; Titball, R. W.; Peacock, S. J.; Cerdeno-Tarraga, A. M.; Atkins, T.; Crossman, L. C.; Pitt, T.; Churcher, C.; Mungall, K.; Bentley, S. D.; Sebaihia, M.; Thomson, N. R.; Bason, N.; Beacham, I. R.; Brooks, K.; Brown, K. A.; Brown, N. F.; Challis, G. L.; Cherevach, I.; Chillingworth, T.; Cronin, A.; Crossett, B.; Davis, P.; DeShazer, D.; Feltwell, T.; Fraser, A.; Hance, Z.; Hauser, H.; Holroyd, S.; Jagels, K.; Keith, K. E.; Maddison, M.; Moule, S.; Price, C.; Quail, M. A.; Rabbinowitsch, E.; Rutherford, K.; Sanders, M.; Simmonds, M.; Songsivilai, S.; Stevens, K.; Tumapa, S.; Vesaratchavest, M.; Whitehead, S.; Yeats, C.; Barrell, B. G.; Oyston, P. C.; Parkhill, J. Genomic plasticity of the causative agent of melioidosis, Burkholderia pseudomallei. Proc. Natl. Acad. Sci. U.S.A. 2004, 101, 14240-14245.

(19) Alexeyev, M. F. The pKNOCK series of broad-host-range mobilizable suicide vectors for gene knockout and targeted DNA insertion into the chromosome of gram-negative bacteria. BioTechniques 1999, 26, 824-826, 828.

(20) de, L. V.; Timmis, K. N. Analysis and construction of stable phenotypes in gram-negative bacteria with Tn5- and Tn10derived minitransposons. Methods Enzymol. 1994, 235 386-405.

(21) Southern, E. M. Detection of specific sequences among DNA fragments separated by gel electrophoresis. J. Mol. Biol. 1975, $98,503-517$
(22) Stevens, M. P.; Haque, A.; Atkins, T.; Hill, J.; Wood, M. W.; Easton, A.; Nelson, M.; Underwood-Fowler, C.; Titball, R. W.; Bancroft, G. J.; Galyov, E. E. Attenuated virulence and protective efficacy of a Burkholderia pseudomallei bsa type III secretion mutant in murine models of melioidosis. Microbiology 2004, 150, 26692676 .

(23) Hennequin, C.; Collignon, A.; Karjalainen, T. Analysis of expression of GroEL (Hsp60) of Clostridium difficile in response to stress. Microb. Pathog. 2001, 31, 255-260.

(24) Beck, F. X.; Grunbein, R.; Lugmayr, K.; Neuhofer, W. Heat shock proteins and the cellular response to osmotic stress. Cell. Physiol. Biochem. 2000, 10, 303-306.

(25) Yang, X. X.; Maurer, K. C.; Molanus, M.; Mager, W. H.; Siderius, M.; Vies, S. M. The molecular chaperone Hsp90 is required for high osmotic stress response in Saccharomyces cerevisiae. FEMS Yeast Res. 2006, 6, 195-204.

(26) Thongboonkerd, V.; Luengpailin, J.; Cao, J.; Pierce, W. M.; Cai, J.; Klein, J. B.; Doyle, R. J. Fluoride exposure attenuates expression of Streptococcus pyogenes virulence factors. J. Biol. Chem. 2002, 277, 16599-16605.

(27) Thongboonkerd, V.; Gozal, E.; Sachleben, L. R.; Arthur, J. M.; Pierce, W. M.; Cai, J.; Chao, J.; Bader, M.; Pesquero, J. B.; Gozal, D.; Klein, J. B. Proteomic analysis reveals alterations in the renal kallikrein pathway during hypoxia-induced hypertension. J. Biol. Chem. 2002, 277, 34708-34716.

(28) Thongboonkerd, V.; Klein, J. B.; Pierce, W. M.; Jevans, A. W.; Arthur, J. M. Sodium loading changes urinary excretion: A proteomic analysis. Am. J. Physiol. Renal Physiol. 2003, 284, F1155-F1163.

(29) Thongboonkerd, V.; Barati, M. T.; McLeish, K. R.; Benarafa, C.; Remold-O'Donnell, E.; Zheng, S.; Rovin, B. H.; Pierce, W. M.; Epstein, P. N.; Klein, J. B. Alterations in the renal elastin-elastase system in Type 1 diabetic nephropathy identified by proteomic analysis. J. Am. Soc. Nephrol. 2004, 15, 650-662.

(30) Thongboonkerd, V.; Chutipongtanate, S.; Kanlaya, R.; Songtawee, N.; Sinchaikul, S.; Parichatikanond, P.; Chen, S. T.; Malasit, P. Proteomic identification of alterations in metabolic enzymes and signaling proteins in hypokalemic nephropathy. Proteomics $\mathbf{2 0 0 6}$, 6, 2273-2285.

(31) Hu, W. N.; Kopachik, W.; Band, R. N. Cloning and characterization of transcripts showing virulence-related gene expression in Naegleria fowleri. Infect. Immun. 1992, 60, 2418-2424.

(32) Chen, Y. Y.; Cross, K. J.; Paolini, R. A.; Fielding, J. E.; Slakeski, N.; Reynolds, E. C. CPG70 is a novel basic metallocarboxypeptidase with C-terminal polycystic kidney disease domains from Porphyromonas gingivalis. J. Biol. Chem. 2002, 277, 23433-23440.

(33) Veith, P. D.; Chen, Y. Y.; Reynolds, E. C. Porphyromonas gingivalis RgpA and Kgp proteinases and adhesins are C terminally processed by the carboxypeptidase CPG70. Infect. Immun. 2004, $72,3655-3657$.

(34) Kikuchi, H.; Kim, S.; Watanabe, K.; Watarai, M. Brucella abortusdalanyl-D-alanine carboxypeptidase contributes to its intracellular replication and resistance against nitric oxide. FEMS Microbiol. Lett. 2006, 259, 120-125.

(35) Fox, D. S.; Cox, G. M.; Heitman, J. Phospholipid-binding protein Cts1 controls septation and functions coordinately with calcineurin in Cryptococcus neoformans. Eukaryotic Cell 2003, 2, 1025-1035.

(36) Khursigara, C.; Abul-Milh, M.; Lau, B.; Giron, J. A.; Lingwood, C. A.; Barnett, Foster, D. E. Enteropathogenic Escherichia coli virulence factor bundle-forming pilus has a binding specificity for phosphatidylethanolamine. Infect. Immun. 2001, 69, 65736579

(37) Naylor, C. E.; Eaton, J. T.; Howells, A.; Justin, N.; Moss, D. S.; Titball, R. W.; Basak, A. K. Structure of the key toxin in gas gangrene. Nat. Struct. Biol. 1998, 5, 738-746.

(38) Titball, R. W. Gas gangrene: an open and closed case. Microbiology 2005, 151, 2821-2828.

(39) Hunt, S. M.; Thomas, M. R.; Sebastian, L. T.; Pedersen, S. K. Harcourt, R. L.; Sloane, A. J.; Wilkins, M. R. Optimal replication and the importance of experimental design for gel-based quantitative proteomics. J. Proteome Res. 2005, 4, 809-819.

(40) Terry, D. E.; Desiderio, D. M. Between-gel reproducibility of the human cerebrospinal fluid proteome. Proteomics 2003, 3, 19621979

(41) Molloy, M. P.; Brzezinski, E. E.; Hang, J.; McDowell, M. T.; VanBogelen, R. A. Overcoming technical variation and biological variation in quantitative proteomics. Proteomics 2003, 3, 19121919

PR060457T 